\title{
QUERERES DE CAETANO: A CANÇÃO COMO LITERATURA EXPANDIDA
}

\section{QUERERES, BY CAETANO: APROACHING THE SONG AS EXPANDED LITERATURE}

\author{
Leandro Ernesto Maia ${ }^{1}$
}

RESUMO: Uma canção lê-se com os ouvidos. É um texto onde os elementos musicais também dizem, falam, gritam, concordam e discordam enquanto as palavras transbordam sonoridades cujo sentido é apenas possível em seu contexto musical, transcendendo o texto escrito. A palavra é matéria sônica, a base que estrutura ritmo, imagens e significados. Como ler-escutar canções em seu contexto de literatura expandida? Este artigo aborda procedimentos de análise intracancional e extracancional para o estudo das canções, evitando a separação entre letra e música em $O$ Quereres, de Caetano Veloso.

$\boldsymbol{P A L A V R A S - C H A V E : ~ c a n c ̧ a ̃ o ~ p o p u l a r ; ~ a n a ́ l i s e ~ c a n c i o n a l ; ~ C a e t a n o ~ V e l o s o ~}$

ABSTRACT: A song needs to be read with the ears like a text where musical elements also say, speak, shout, agree and disagree. The words, at the same time, overflow sounds whose meaning lies in their musical context, transcending the written text. The word is a sonic matter, the basis that structures rhythm, images, and definitions. How to read-listen to songs in the context of expanded literature? This article discusses intersong and extrasong procedures for studying songs avoiding the split of lyrics and music of the song $O$ Quereres, by Caetano Veloso.

KEY-WORDS: popular song; song analysis; Caetano Veloso

\section{INTRODUÇÃO}

A Canção - assim, em maiúsculas - é um gênero artístico que contém as suas especificidades como um gênero próprio a ser lido com os ouvidos, feito música, mas envolvendo outras camadas de significação, sobretudo no campo dos Estudos Literários. $O$ Quereres relaciona as formas poéticas eruditas com a entoação repentista. Funde o decassílabo heroico com a nordestinidade seca, heroica à sua maneira. Inquietante ao mesmo tempo resignada frente ao paradoxo incansável de um querer inalcançável. O eterno em três minutos.

Um verdadeiro tratado sobre a ambiguidade, sendo esta uma das propriedades do desejo, O Quereres é tida como um dos grandes textos de Caetano Veloso. Ocorre que, sendo uma canção, este texto apresenta-se cantado em letra e música, proporcionando uma relação mais ampla de significação. Para todos os efeitos, estamos tratando da primeira gravação desta canção, presente no disco Velô, de 1984, cuja produção musical é assinada por Caetano

\footnotetext{
${ }^{1}$ Mestre em Literatura pela UFRGS.
} 
Veloso juntamente com Ricardo Cristaldi ${ }^{2}$. O Quereres é a sétima faixa do álbum, um show-disco que flerta com da música pop, com a poesia concreta, com a língua inglesa e o português, com ritmos brasileiros como o frevo e o maracatu. Ao estudar a dicção de Caetano Veloso, Luiz Tatit afirma:

Esse eterno desespecialista que, ao produzir, toca profundamente o ouvinte é a versão mais bem acabada do cancionista, aquele que realiza uma alquimia com ingredientes de diversas áreas e obtém um produto autônomo, responsável por uma esfera de conteúdo impenetrável por outras estéticas (TATIT, 2002, p. 2073).

Poder-se-ia esperar um depoimento detalhado de Veloso sobre esta canção. No entanto, em Sobre as Letras, organizado por Eucanaã Ferraz, Caetano é extremamente econômico:

A estrutura é tirada de cordel. Mas também tem um pouco de "It ain't me, babe", de Bob Dylan, que diz: "it ain't me you're lookin' for, babe". Lá é diferente, mas alguma coisa em "O Quereres" lembra esse tema, do homem que fala para a mulher: "eu não estou aonde você quer" (VELOSO, 2003, p. 56).

Como chegar ao que o compositor revelou apenas em forma de canção? A fim de não cairmos na tentação de separar letra e música, analisaremos aspectos intracancionais e extracancionais. O primeiro aspecto tratará dos elementos intrínsecos à relação melodia-letra, o estabelecimento dos motivos e temas musicais, a produção do texto e seu desenvolvimento no decorrer da composição. O segundo, tratará a canção em sua leitura ampla, relacionando-a a outros textos e contextos musicais e literários.

Dentre as disciplinas que estudam as relações entre letra e música, tais como a Semiótica da Canção (TATIT, 1986), encontramos a Melopoética, do teórico Steven Paul Scher (OLIVEIRA, 2002). Para Solange Ribeiro de Oliveira, Scher realiza uma tipologia de três divisões básicas. A primeira:

contempla as criações mistas que incluem simultaneamente o elemento verbal e o musical. Destaca-se aí a ópera, especialmente o drama musical de Wagner, o lied, a canção, em geral, bem como investigações sobre a sinestesia, a melopeia e aspectos acústico-musicais da linguagem verbal. (OLIVEIRA, 2002, p. 12).

A segunda divisão básica é a dos “estudos focalizando a literatura na música, ou estudos literário-musicais, que recorrem a conceitos ou procedimentos de crítica literária para

\footnotetext{
${ }^{2}$ Ficha Técnica de O Quereres: Ricardo Cristaldi: teclados; Zé Luis: Sax e Flauta; Tavinho Fialho: Guitarra; Toni Costa: Baixo; Marçal: percussão; Marcelo Costa: bateria
} 
instrumentalizar a análise musical" (OLIVEIRA, 2002, p. 12). A terceira tipologia trata de música na literatura:

Entre os vários objetos de análise encontram-se: a música de palavras; recriações literárias de efeitos musicais ("música verbal", na terminologia de Scher); a estruturação de textos literários sugestiva de técnicas de composição musical, como na utilização deliberada ou intuitiva, da forma sonata, do contraponto e de tema e variação; o papel de alusões e metáforas musicais na obra literária, aí incluída a figura do músico. (OLIVEIRA, 2002, p. 13).

O presente trabalho poderia situar-se na primeira tipologia - criação mista que inclui os elementos verbais e musicais. Como exercício de exemplificação do segundo tipo literatura na música, poderíamos citar a dissertação de Fernando Lewis de Mattos (MATTOS, 1997) sobre Salamanca do Jarau, bailado composto por de Luís Cosme em 1935 que trata do estudo comparativo entre o conto homônimo de João Simões Lopes Neto e seu reflexo na composição musical. No terceiro tipo, ou música na literatura, poderíamos exemplificar o doutorado de Eduardo Dall'Alba, sobre a metáfora da noite e música na poesia de Carlos Drummond de Andrade (DALL'ALBA, 2003). Entendemos estes trabalhos como passíveis de classificação nesta tipologia, ainda que seus autores não os tenham situado desta maneira.

Esta disciplina, além da tipologia tripartite apontada por Scher se divide em duas grandes orientações genéricas que são complementares e não-excludentes. A primeira orientação genérica é a Melopoética Estrutural; técnica, formalista e específica; enquanto a segunda é Melopoética Cultural, de matriz interpretativo-cultural (OLIVEIRA, 2002, p. 43).

Mesmo não utilizando estritamente as tipologias e procedimentos analíticos mencionados por OLIVEIRA, verifica-se a compatibilidade entre as metodologias. A divisão deste trabalho em dois momentos mistos (intramelódico-textualidades/aspectos intracancionais e extramelódico-textualidades/aspectos extracancionais) contempla Melopoética Estrutural e Melopoética Cultural sem que tenhamos de seguir estritamente esta ou aquela metodologia.

Os aspectos intracancionais envolvem o nível intramelódico através de gestos musicais - motivos e temas - e sua relação dentro da canção. Neste momento estudaremos a maneira como são construídas as frases musicais, a presença de jogos de pergunta e resposta, as relações entre melodia, harmonia e ritmo. Junto ao estudo da construção melódica verificaremos sua relação com a manufatura do texto, ou seja, o nível intratextual, que se 
refere à construção interna do discurso verbal, a maneira como o compositor resolve internamente forma e conteúdo. O nível básico para analisarmos uma canção no que se refere à melodia e letra é, portanto, o das intramelódico-textualidades.

Os aspectos extracancionais dizem respeito ao nível extramelódico que ocorre através da relação externa da canção com outras canções, da música com outros gêneros musicais no cruzamento de suas tradições e características. Percebemos, aqui, a vinculação da canção dentro de seu contexto cultural, a presença de citações musicais, sua aproximação com outros gêneros como maracatu, samba, coco, embolada, baião, rock, etc. Neste nível buscaremos entender as características de determinado gênero bem como compreender a maneira como determinado ritmo influencia no pensamento geral da canção, sua estrutura rítmica compatibilizada como uma estrutura de pensamento. O nível extratextual busca o entendimento da canção através de um ponto de vista mais amplo, contemplando um diálogo com a tradição literária e com teorias que possam auxiliar a elucidação da obra. É o momento da análise de uma canção relacionando-a a outros autores e obras, feita a partir de apontamentos de Caetano Veloso em diversos escritos, bem como aqueles encontrados em $O$ Quereres durante a análise preliminar. É o campo da intertextualidade, do entendimento do estilo e dos elementos da cultura em que o compositor encontra-se inserido.

É importante, mais uma vez, salientarmos que esta opção metodológica visa estabelecer uma vinculação indissolúvel de letra e música, reconhecendo isto em todos os níveis de análise - desde a construção interna da melodia de cada palavra e frase até a relação de uma canção com outras obras, sejam elas canções, romances, contos, poemas, filmes, etc. Busca-se, portanto, evitar a dissociação que poderia até mesmo induzir equívocos na hora de definir e estudar a canção. A bipartição que vislumbramos não é a tradicional separação entre letra e música, mas a separação entre uma análise interna (estrutural) e externa (cultural).

O ponto de partida, deve-se reconhecer, é intuitivo e subjetivo. Parte-se de uma inquietação não necessariamente racional em relação à obra em questão para, então, compreender os mecanismos pelos quais tais efeitos são provocados em nossa percepção. Neste sentido, os aspectos intracancionais tendem a se caracterizar pela fragmentação e pela objetividade nos tópicos, enquanto os aspectos extracancionais tendem a um caráter mais ensaístico: os assuntos vão se encadeando de acordo com um certo fluxo de temas, suscitados a partir dos próprios textos. MEYER, chama-nos atenção sobre esta dinâmica que conciliar intuição e análise: 
crítica (musical) visa explicar como a estrutura e o processo de uma composição específica estão relacionados na compreensão de um ouvinte competente. Em outras palavras, o papel da crítica musical é semelhante ao da crítica literária. (...) o crítico não pode, a meu ver, começar com princípios estéticos e terminar com julgamento crítico. Exatamente o contrário. Ele parte das suas próprias impressões - seu senso cognitivo-afetivo de que uma composição é convincente e interessante, intrigante e divertida. Somente então ele tenta achar um motivo racional para o seu julgamento (MEYER, 1973, p. IX) ${ }^{3}$

Existem intercorrências entre entre o processo analítico musical e o literário: ambos partem da obra que nos capta pela intuição, buscando compreender os mecanismos propositais ou não - pelos quais nossa intuição e curiosidade são provocadas. Objetiva-se aqui compreender o que torna $O$ Quereres uma obra digna de atenção.

\section{ASPECTOS INTRACANCIONAIS}

Desde a introdução no teclado, O Quereres evidencia ambiguidades harmônica e melódica através da articulação contínua das notas dó e ré através dos acordes C9omit3 e $D / C$ :
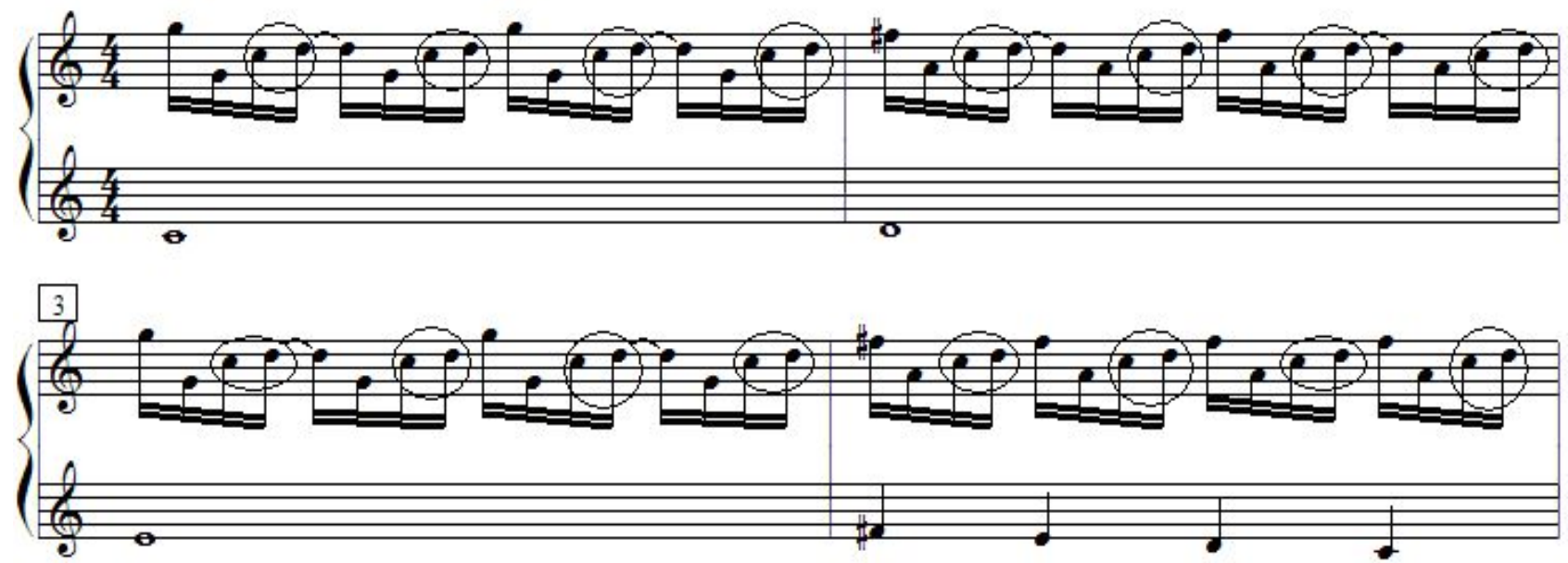

\footnotetext{
${ }^{3}$ Meyer, 1973, prefácio, p. IX: criticism seeks to explain how the structure and process of a particular composition are related to the competent listener's comprehension of it. In other words, the role of music critic is similar to that of the literary critic. (...) but the critics does not, I think, begin with aesthetic principles and arrive at critical judgments. Quite the opposite. He begins with his own responses - his cognitive-affective sense of whether a composition is convincing and exciting, intriguing and entertaining. Then he attempts to find rational grounds for his judgment.
} 
As notas dó e ré - grifadas acima - estão presentes em todos os compassos da introdução, quatro vezes em cada compasso. As notas agudas alternam-se entre sol - que valoriza a nota $d o ́$ - e fa\# - que se opõe a dó e valoriza a nota ré. Temos aqui apenas quatro compassos executados pelo teclado que introduzem os dois acordes principais a serem desenvolvidos (C9add e D7), além da apresentação do ritmo básico de acompanhamento semelhante ao coco, ou baião. Segue-se a primeira estrofe:
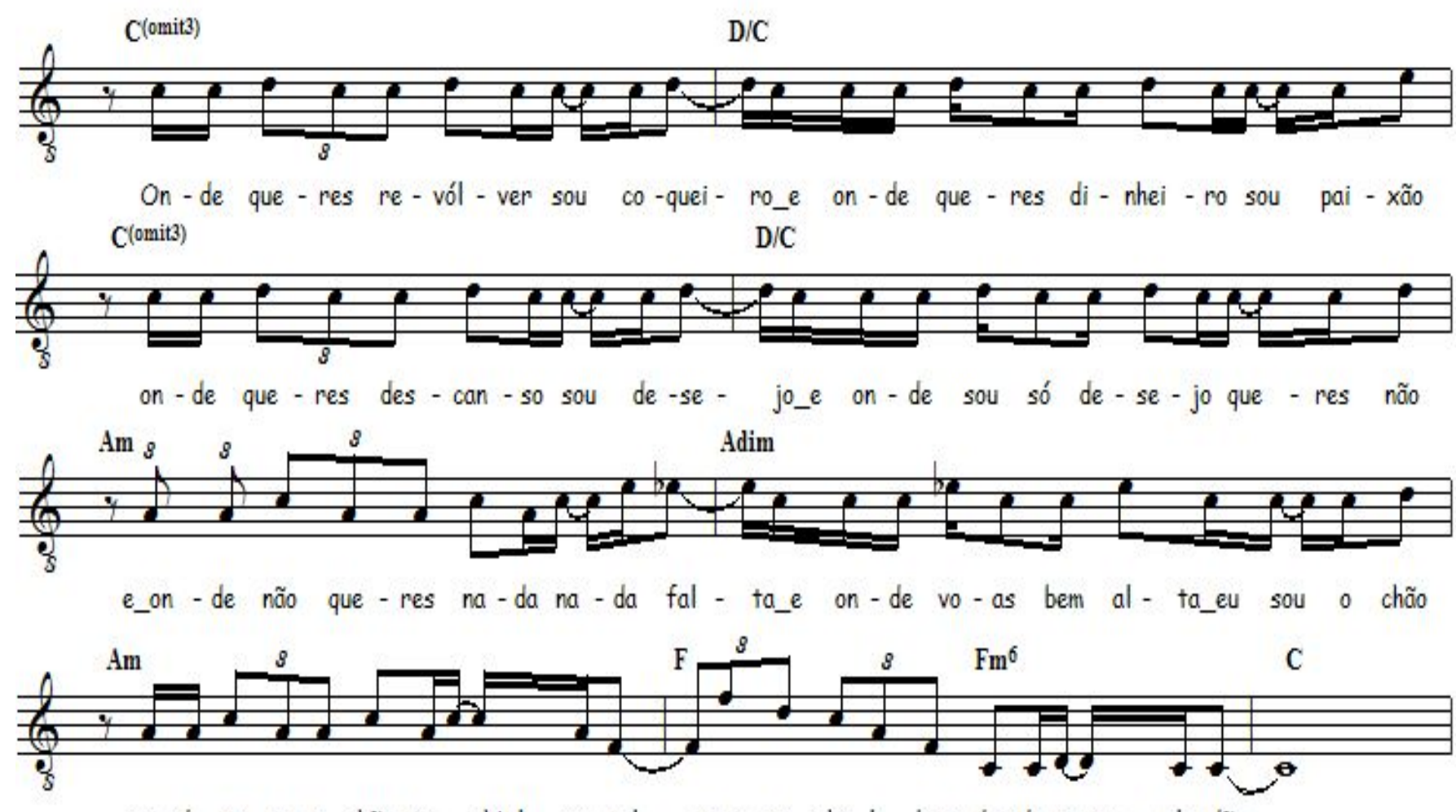

on-de pi-sas o chão mi - nh'al - ma sal- ta_e ga-nha li--ber-da-de na_am - pli-dão

Notemos que o tema é elaborado basicamente em dó (espaço) e ré (linha). A nota mais aguda (ré) aparece junto às sílabas tônicas do texto, apresentando figuração rítmica mais longa, evidenciando a melodia interna das palavras:




Note-se que a melodia permanece a mesma nas estrofes, que variam de texto a cada repetição musical. A equivalência prossegue em cada verso resultando numa frase musical, onde palavras e música confluem numa mesma estrutura. Desta forma, existe uma relação direta entre texto e música, entendida como paralelismo semântico:

O processo composicional paralelismo semântico vai ao encontro do texto ao garantir a sua compreensibilidade pelo ouvinte, confirmando uma convergência perceptiva (CHAVES e NUNES, 2003, p. 69).

Conforme o diagrama de transcrição melódica desenvolvido por TATIT (2002), teríamos :

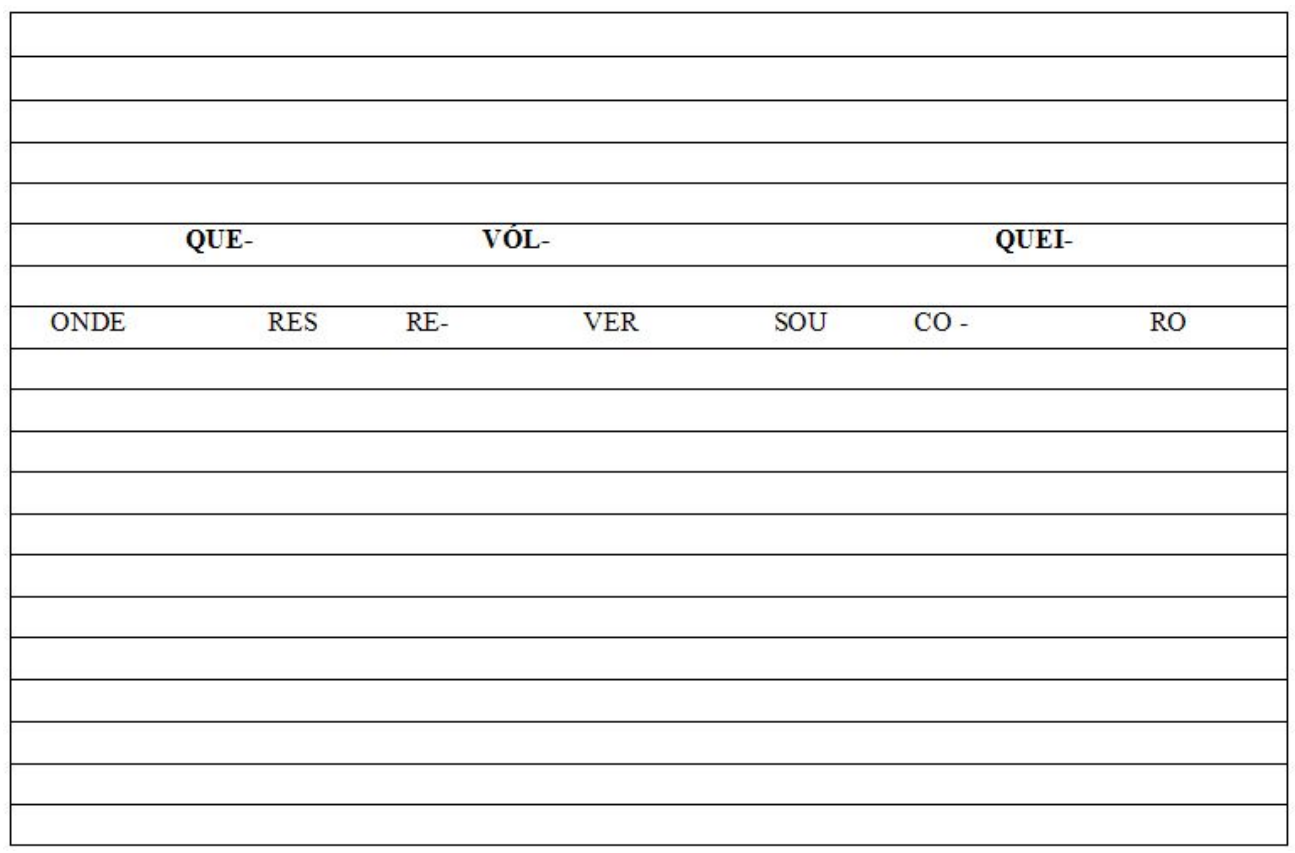

É interessante percebermos como a letra é tratada no tema. Conflui com o tema musical o aparecimento de curiosos paradoxos e antíteses. Opõe-se revólver a coqueiro. Os substantivos tomam o lugar da ação que é gramaticalmente reservado aos verbos. Cria-se uma sintaxe própria já nos primeiros versos ao colocar em polos opostos substantivos comuns que, usualmente, não apresentam oposição entre si. Um dos primeiros gestos de Caetano Veloso passa pela substantivação do querer do outro - O Quereres - ao mesmo tempo em que "pronomiza" e "verbaliza" os substantivos, desloca as palavras - também coisas - dos seus lugares comuns. Como prova da valorização musical dos substantivos ouvimos a voz salientar

\footnotetext{
${ }^{4}$ Este diagrama de transcrição melódica representa o campo tessitura utilizado pela canção, e nos espaços, pelos quais transitam as sílabas da letra, representam a progressão em semitons.
} 
- através da utilização de vibrato $^{5}$ - a sílaba tônica de coqueiro, entoada com a nota ré. O que podemos perceber, no que se refere à utilização do vibrato por Caetano nesta canção, é que é realizado sempre no segundo substantivo em comparação com o primeiro. Desta forma, temos:

\section{revólver (sem vibrato) x coqueiro (com vibrato) \\ dinheiro (sem vibrato) x paixãa (com vibrato)}

Este procedimento performático ocorre durante toda a canção e ocorre coincidindo com as notas longas. Ornamentando o segundo substantivo de cada sentença - que equivale valorizar o eu em relação ao $t u$ - percebemos a maneira como o cantor/compositor se posiciona frente ao texto e se "oposiciona" frente ao outro. Utilizando-se de vibrato, portamento $^{6}$ e nuances de articulação e pausa, o cantor parcimoniosamente desenvolve uma linearidade narrativa paralela, conduzida exclusivamente pela vocalidade. É o timbre vocal a serviço da mensagem. As sílabas tônicas em $O$ Quereres são reforçadas pela duração, pela altura e pelo timbre vocal. As palavras são valorizadas e destacadas através da melodia e da articulação.

O tema inicial é sustentado harmonicamente pelo acorde que poderíamos caracterizar como Dó Maior $(C)$, embora tenha a terça $(m i)$ omitida. É adicionada a nona (ré), numa configuração harmônica que tende ao sistema modal com acordes quartais: C(9)3omitt: dó, sol, ré. Para os leitores que não conhecem Harmonia Musical, o que realmente interessa é constatar que a utilização deste tipo de combinação de sons agrupados (acorde) resulta num efeito marcado pela indefinição sonora, pela ambiguidade que não se caracteriza nem maior nem menor, mas aberta e com tendência à estabilidade. Temos, desde o primeiro acorde arpejado da canção, uma ambiguidade musical estabelecida.

\footnotetext{
${ }^{5}$ Técnica e efeito ornamental que consiste na alteração da frequência de uma nota (...). Empregado como elemento expressivo, de grande valor para o intérprete, surge quase que naturalmente entre cantores e, geralmente, por estudo técnico entre os instrumentistas de cordas e sopros. (DOURADO, 2004 p. 353). ${ }^{6}$ Deslizamento intencional ou não, na mudança entre uma nota e a que lhe segue. É bastante comum na voz humana, bem como em instrumentos não temperados como o violino e o trombone. (DOURADO, 2004, p. 260). Pode também ser traduzido como um pequeno glissando, ou deslize.
} 


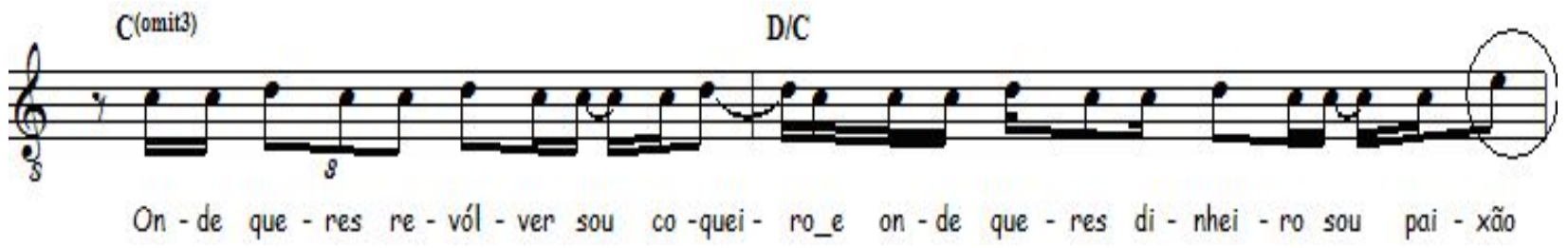

A entoação da palavra "paixão" com a nota $m i$ - no contexto de alternância entre dó e ré - cria um efeito de reforço melódico que acaba mimetizando com maior ênfase o estado passional do sujeito. Onde queres revólver (violência, ameaça, briga, fogo, explosão), sou coqueiro (tranquilidade, sombra, paz, ócio, contemplação) e onde queres dinheiro (matéria, riqueza, trabalho, compromisso), sou paixão - substantivo abstrato contrapondo-se a todos os objetos representados com as notas dó e ré, ou seja, substantivos concretos. A nota $m i$ cria um efeito enorme, se consideramos que é a terça do acorde maior: literalmente é a nota que tem a função de expressar o afeto.

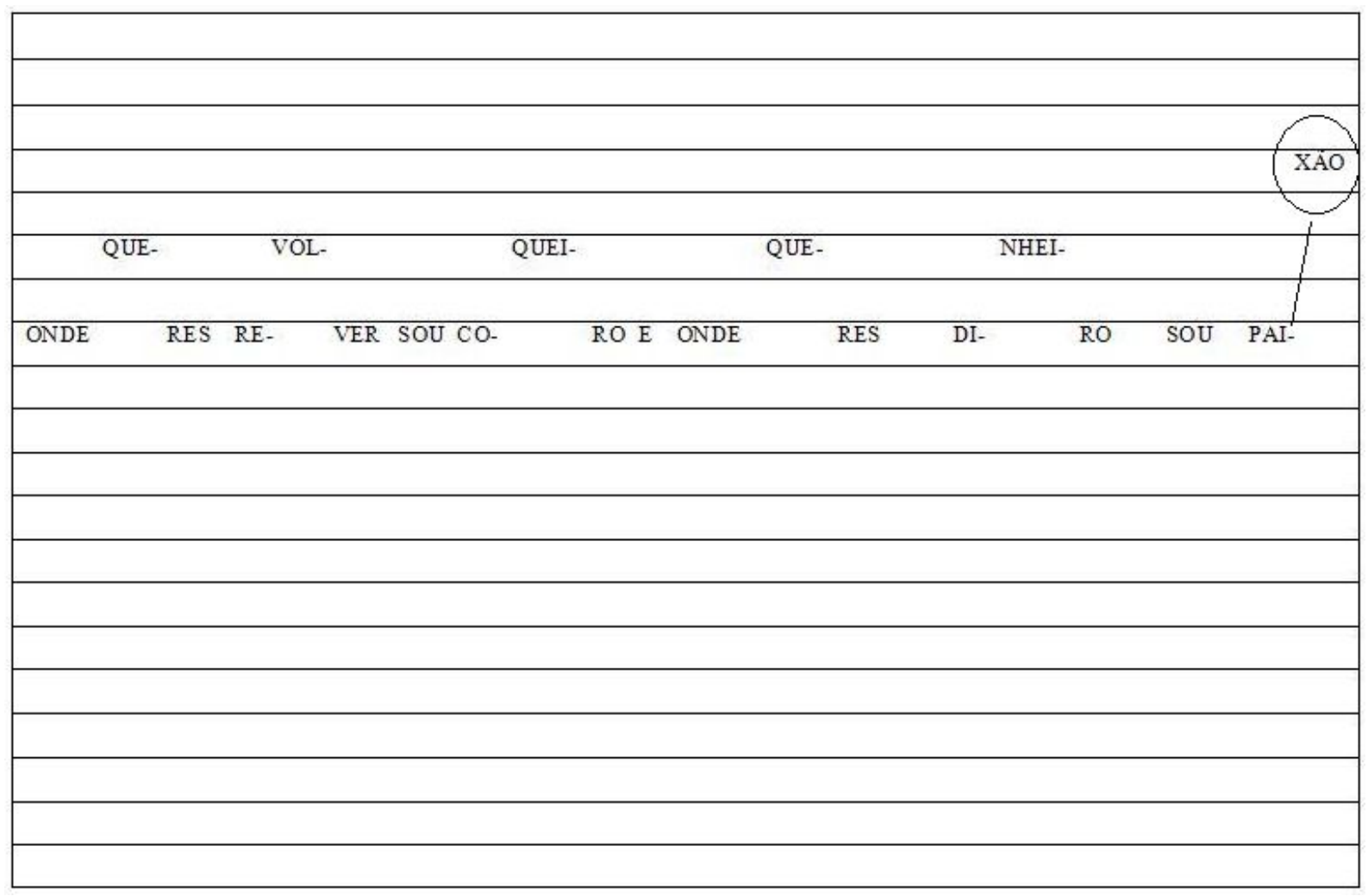

Comparando os dois primeiros versos, existe uma significativa variação melódica, ainda que tênue: a última nota da primeira frase é $m i$, e a segunda é ré: 



Esta modificação melódica soa como uma quebra de expectativa que faz com que o ouvinte se "engane", fazendo uma oposição à paixão afirmada anteriormente. Isto é reforçado pelo acorde que sucede este trecho, lá menor (Am): num procedimento conhecido como cadência deceptiva, ou seja, ao invés da sequência harmônica retornar para Dó Maior (C), é conduzida para o relativo menor (Am). A palavra "não" é entoada com a nota ré e tem o seu significado de negação enormemente ampliado pelo diálogo da melodia com o acompanhamento. A melodia do tema é repetida literalmente em Onde sou só desejo, queres não, mas é desconstruída pelo acompanhamento. A negação é dada pela harmonia (Am).

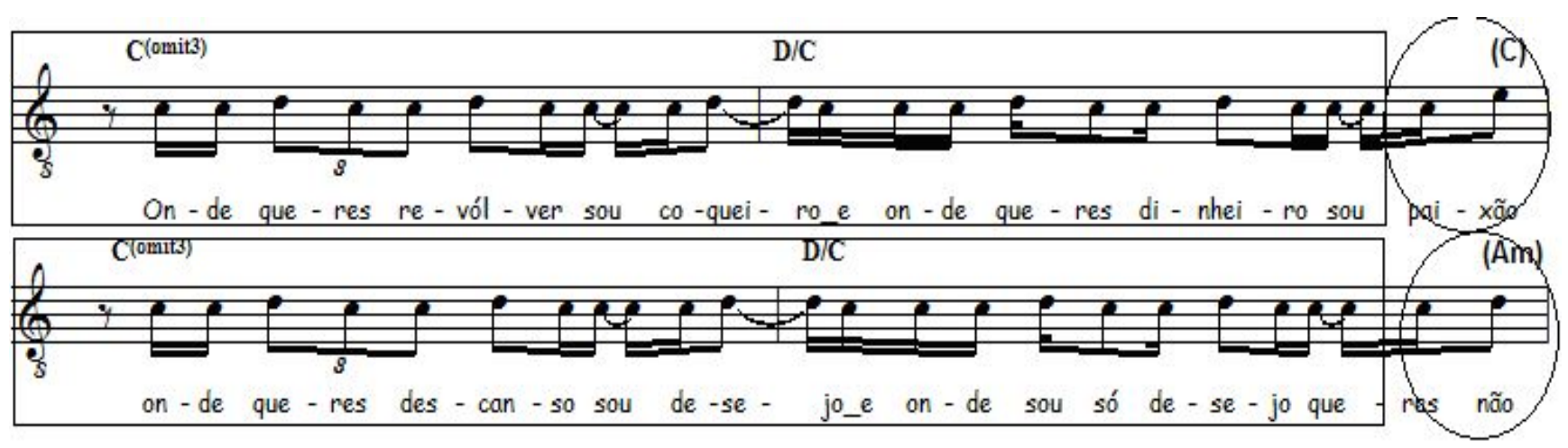

No campo semântico podemos perceber a estreita relação entre a classe gramatical das palavras e sua função melódica: 
revólver, sou coqueiro

dinheiro, sou paixão

- muda melodia

descanso, sou desejo

desejo, queres não

- muda harmonia

cadência deceptiva

substantivo concreto, sou substantivo concreto
substantivo concreto, sou substantivo abstrato

- muda melodia

substantivo abstrato, sou substantivo abstrato

substantivo abstrato, queres advérbio

- muda harmonia

cadência deceptiva

É como se verificássemos que as relações que ocorrem dentro da mesma classe gramatical são melódicas (alturas), e as relações entre classes gramaticais diferentes são harmônicas (acordes). Isto prossegue de forma mais acirrada na hora dos não-quereres, quando a estrutura melódico-semântica anterior é desmantelada, ou seja: a melodia se modifica, a harmonia se expande e as classes gramaticais se alternam.

Evitando esmiuçar nota a nota e acorde por acorde, cabe ainda destacar a emblemática presença de madrigalismo, procedimento de mimese musical conhecido como "pintura de palavras", precisamente no verbo saltar, presente no penúltimo verso: 
Temos, neste caso bastante típico, uma coincidência entre a ação verbal (saltar) e o gesto musical, onde a melodia literalmente realiza um salto - de uma oitava ascendente. Este gesto incisivo é imediatamente compensado pelo movimento descendente, conduzindo o trecho para o repouso e para a "amplidão" com nota longa. O ritmo, agora em tercinas, é modificado de modo a representar a liberdade. A palavra amplidão é representada pela nota dó grave entoada com nota longa (mais ampla) e vibrato. Interessante o caráter expresso em música denotativo da palavra amplidão: repouso, tranquilidade, demora, nada de pressa ou tensão. A amplidão é representada pela música como um ponto de chegada.

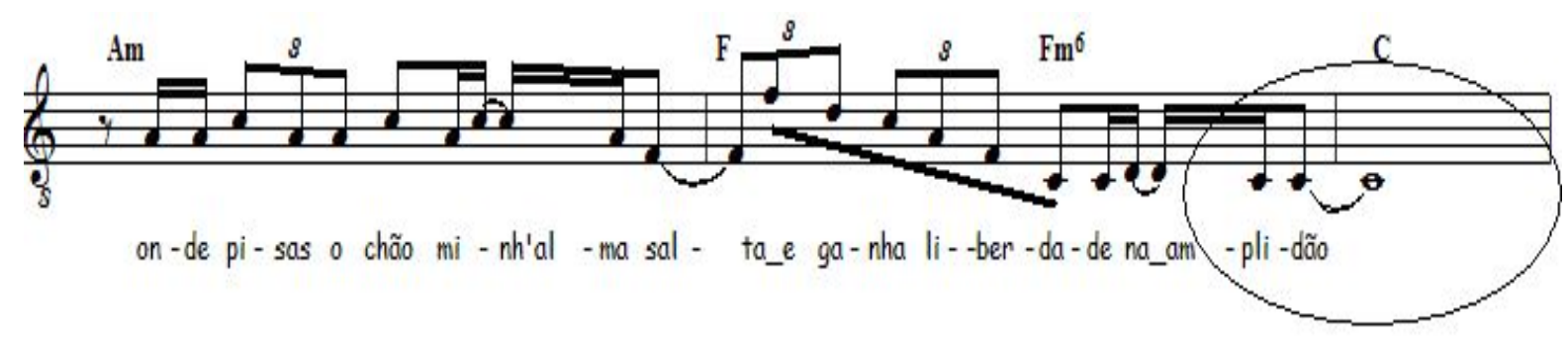

Conforme o modelo de Tatit, teríamos: 


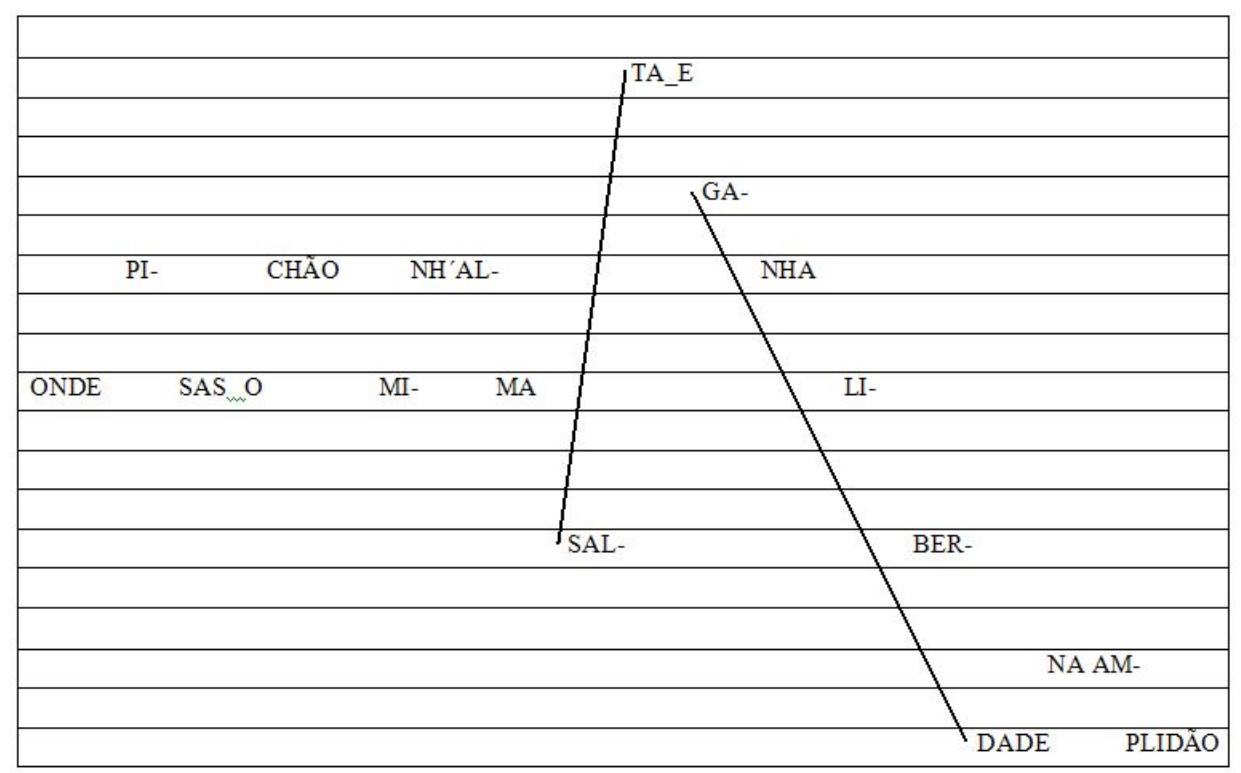

Percebemos na primeira estrofe de $O$ Quereres uma espécie de apresentação do universo inicial da canção, como foram realizadas as primeiras relações entre letra e música. O estabelecimento das primeiras regras. Estas mesmas relações e regras serão, a partir de agora, também objetos de construção e de desconstrução para o compositor. A partir da segunda parte da canção, o cancionista passa a contar não somente com os materiais melódicos, rítmicos, harmônicos, textuais, motivos e temas - da primeira parte, mas pode se utilizar das próprias regras estabelecidas. Estas também se tornam, a partir de agora, material para a composição.

O estribilho é trabalhado de maneira a quebrar a ordem previamente estabelecida pelas estrofes. Percebemos que agora é o texto que se repete, enquanto a melodia varia sendo caracterizada pela utilização de notas longas, andamento mais lento e de um registro vocal mais agudo. Ah bruta flor do querer/ah bruta flor, bruta flor. No refrão ocorre, ainda, um contraste estrutural: o estabelecimento da redondilha maior, não mais o verso decassílabo. Isto é acompanhado pela mudança de tonalidade, bem como uma alteração significativa da instrumentação: o aparecimento de instrumentos de sopro, a presença marcante dos efeitos de percussão e a linha melódica do baixo executado com a utilização de sons harmônicos ${ }^{7}$.

\footnotetext{
7 Harmônico natural: Som harmônico que é obtido quando um dedo da mão esquerda toca levemente determinado ponto de uma corda solta, ao mesmo tempo em que ela é tangida, pinçada ou percutida. DOURADO, 2004, p. 157. Os harmônicos são sons mais agudos e têm a função, entre outras, de expandir a tessitura dos instrumentos.
} 


\begin{tabular}{|l|l|}
\hline \multicolumn{1}{|c|}{ ESTROFE } & \multicolumn{1}{c|}{ ESTRIBILHO } \\
\hline Presença do Decassílabo & Presença do Heptassílabo/Redondilha \\
Articulação dos instrumentos com & maior \\
sons naturais & Predominância do modo Menor; \\
Predominância do modo Maior; & A nota sol é mais significativa em \\
A nota dó é mais significativa em & termos de duração; \\
termos duração; & Tessitura vocal mais exigente em \\
Tessitura vocal mais confortável ao & termos de duração e alturas: notas \\
cantor, partindo da região média & mais longas e mais agudas; \\
repousando na região grave; & Maior “iconicidade", texto marcado \\
Maior narratividade, texto mais & pela presença da interjeição "Ah" e \\
"prosaico", com maior variabilidade & pela repetição textual; \\
textual, sem a presença de & Não há evidência de um interlocutor \\
onomatopeias, interjeições ou & explícito. O refrão pode representar \\
repetições; & um diálogo interno do cantor ou a \\
Utilização de dêiticos e a presença de & reflexão exterior e distanciada; \\
um interlocutor evidente ou reflexão & \\
mediante a presença do “outro" & \\
subentendido; & \\
\hline
\end{tabular}

Desta forma, baixo elétrico, instrumento grave, rude e bruto é tocado de tal maneira que parece representar a delicadeza de uma flor, bruta flor, da mesma forma em que o sax soprano, tradicionalmente mais delicado, é tocado com agressividade. A sonoridade natural dos instrumentos é relativizada pela sua articulação - o que garante uma grande expressividade sem perturbar o equilíbrio necessário à compreensão do todo. $\mathrm{O}$ bruto se revela delicado e o delicado se revela bruto. Eis a mensagem sonora do refrão: 


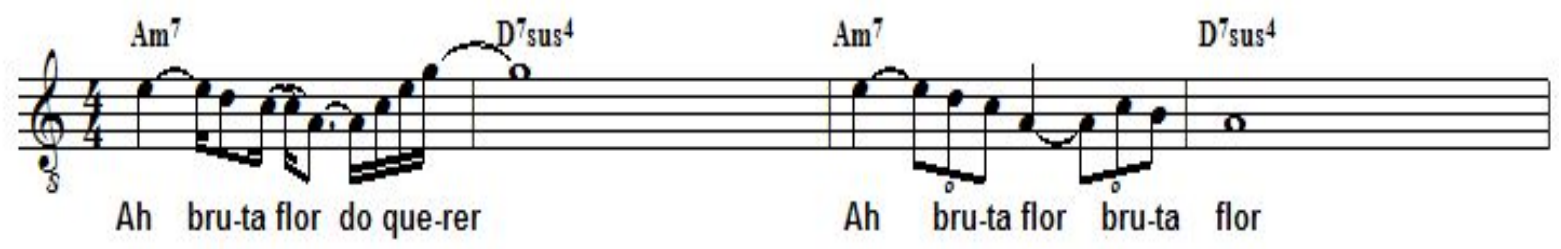

Para Tatit, teríamos:

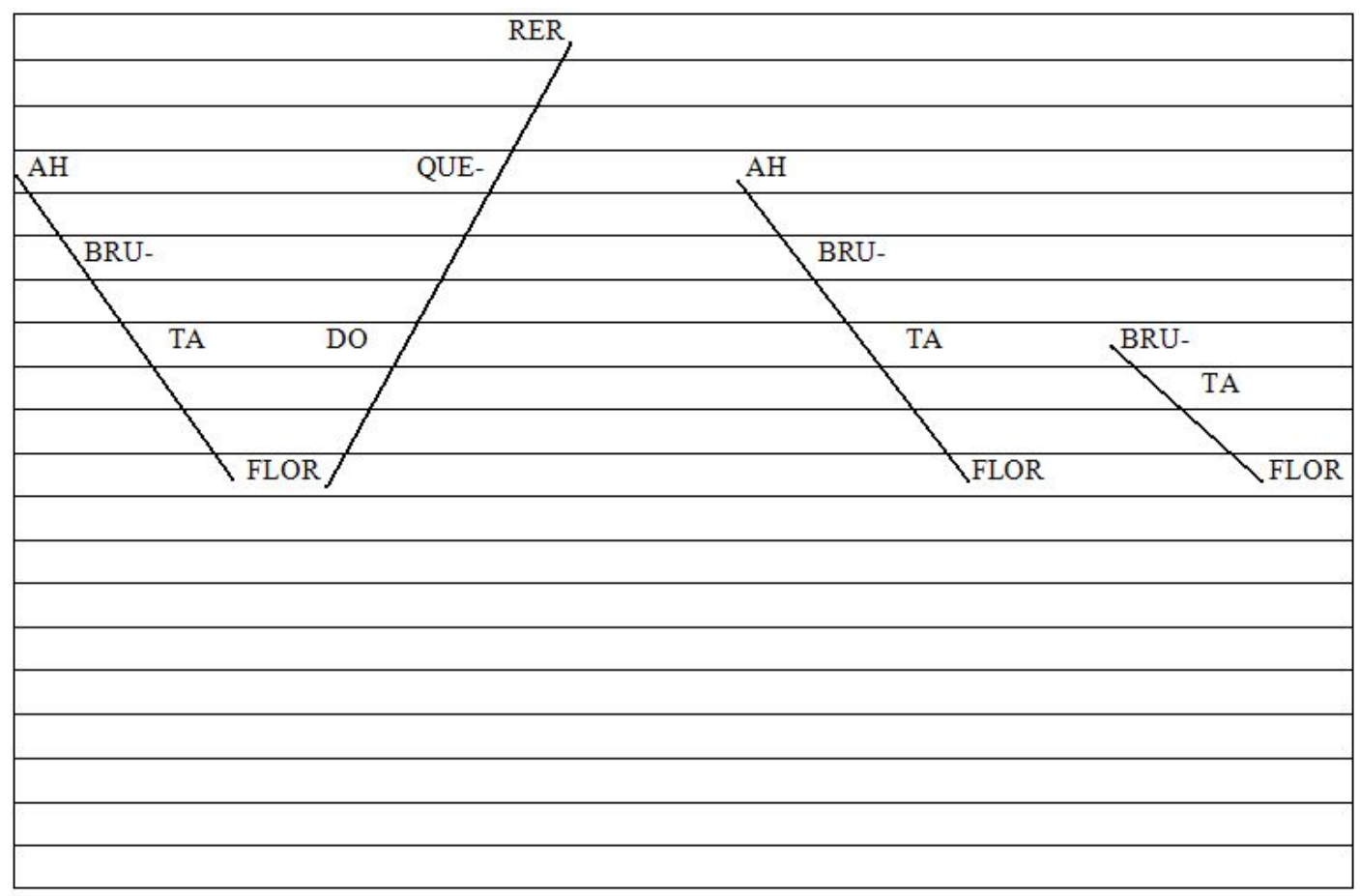

Podemos observar logo de início que o estribilho apresenta a parte mais tensa melodicamente, ou seja, é entoado com notas mais agudas e de maior duração. A interjeição $A h$ é bastante valorizada nas duas aparições, sendo até aqui a nota mais longa de toda a canção. A utilização deste termo já é por si só, uma escolha pela indefinição, já que $A h$ pode denotar tanto alegria, como lamento ou espanto.

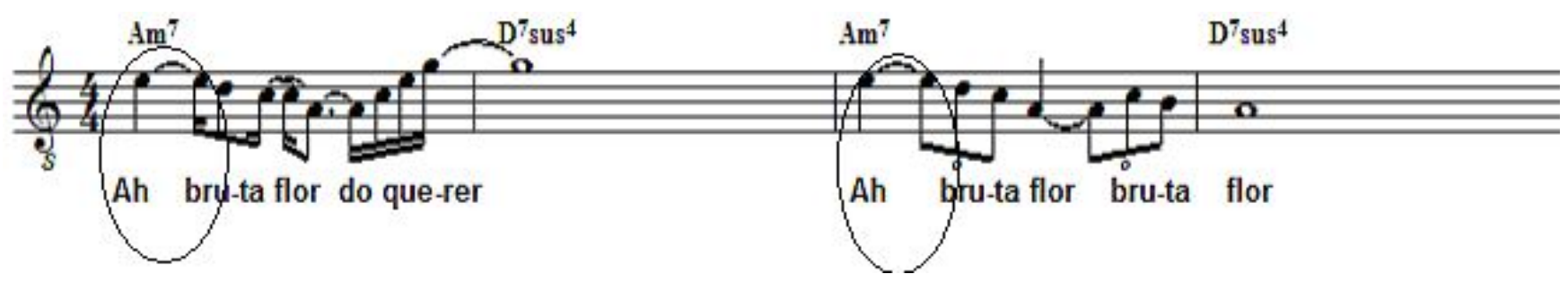


Bruta Flor é uma imagem que expressa esta ambiguidade e dialoga com a poesia moderna ao desconstruir imagens poéticas cristalizadas. Tais como A Flor e a Náusea de Carlos Drummond de Andrade, ou ainda As Flores do Mal, de Baudelaire, a canção propõe novas relações. É uma afirmação de que o querer contém o não querer e pode ser representado pela imagem da Bruta Flor. Temos, no estribilho um sentimento complexo, misto de lamento e espanto, frente à revelação contraditória. Uma espécie de síntese do conflito humano. Tão presente na poesia barroca, como veremos nos aspectos extracancionais.

Curiosamente, e não por acaso, a emissão vocal mais aguda de toda a canção é dada na palavra querer cantada com a nota sol, e ocorre apenas uma vez. Isto é extremamente significativo. O querer, na sua forma infinitiva, ocorre somente no estribilho e no último verso da canção.



Este trecho apresenta uma situação harmônica bastante peculiar, já que é acompanhado por um acorde sus, ou seja, com a quarta suspensa e sétima, que sugere uma resolução de terça que não ocorre. O acorde Résus7 é formado pelas notas ré, sol, lá, dó, omitindo fá\# que, numa condução harmônica mais convencional seria introduzido através de um retardo sol-fa\#. Este tipo de condução de vozes é evitado por Caetano quando canta o refrão de $O$ Quereres, o que denota uma busca pela suspensão como efeito predominante neste trecho. Neste sentido, a palavra querer, cantada como suspensão, causa realmente um efeito de carência: a nota sol quer ser resolvida em fá\#. O refrão é caracterizado, assim, pela presença física do querer através da utilização destes recursos musicais. 


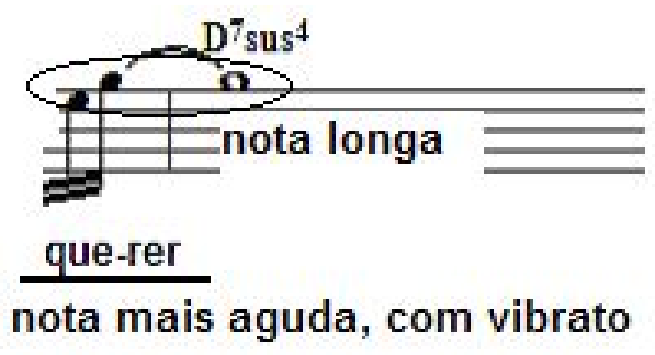

\section{ASPECTOS EXTRACANCIONAIS}

Vale ressaltar que os aspectos extracancionais são, em certa medida, sugeridos por elementos intracancionais. É o caso da finalização das estrofes, que ocorre sempre da mesma maneira: a tônica é atingida por movimento descendente sendo reforçada pela repetição e pela bordadura superior.

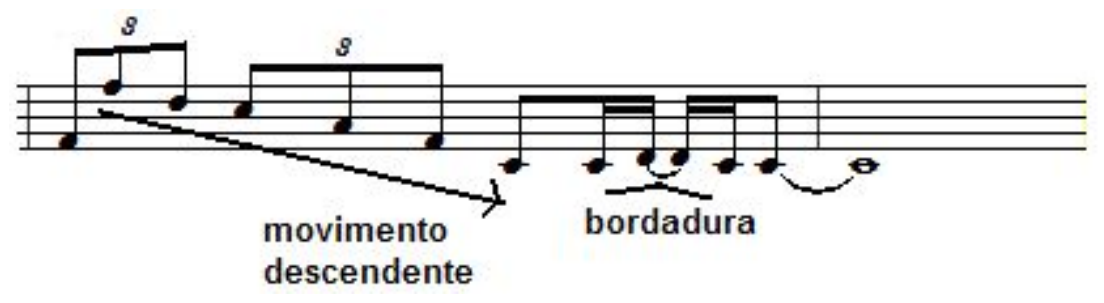

Esta finalização feita por bordadura superior é bastante comum na tradição musical nordestina. Este motivo melódico que encerra as estrofes resume e condensa a dualidade das notas dó e ré. Poderia, sem prejuízos à estrutura da melodia principal, ser utilizado como ostinato - numa espécie de mantra que pode ser repetido durante todo o ritual enunciativo.

A melodia de $O$ Quereres evidencia a entoação nordestina através da dicção, da prosódia e da organização dos sons utilizados em sua escala. Quando Caetano Veloso diz que a estrutura desta canção é "tirada do cordel", está se referindo não somente à estrutura dos versos - o quadrão, oitava de poesia popular formada por duas quadras - mas também à estrutura musical, que se organiza no sistema modal típico da música rural brasileira.

Pensarmos $O$ Quereres a partir do sistema modal pode nos revelar algo. A nota mais grave da melodia é a própria dó, que é a tônica. Interessante percebermos que a nota mais aguda da canção - sol - ocorre somente no estribilho associada à palavra querer: 


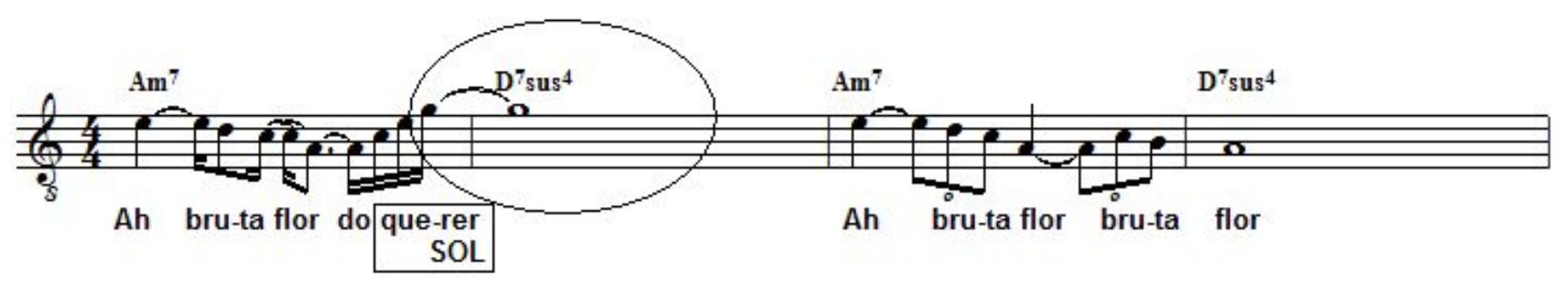

Relaciono $O$ Quereres ao sistema modal por empregar procedimentos que privilegiam a sucessão de acordes ao invés do encadeamento, ou progressão, característico do sistema tonal. A sucessão modal difere-se do encadeamento tonal devido à utilização individualizada de cada acorde por sua “cor" sonora, e não por sua função harmônica - embora estas cores, texturas ou timbres possam exercer também funções de tensão e repouso criando narrativas musicais paralelas. Uma harmonia de encadeamento, diferentemente, privilegia as relações de progressão entre os acordes, o seu vínculo hierárquico e a busca de um direcionamento que atua como pano de fundo para a melodia.

O Quereres tem a regionalidade bastante evidente quando ouvimos a versão de violão e voz de Caetano Veloso, no disco Totalmente Demais (1986) - gravado nos Estados Unidos. Neste registro, Caetano entoa até mesmo o nham, nham, nham característico do gênero, como se fizesse uma toada repentista.

A melodia em $O$ Quereres, e possivelmente em boa parte da obra de Caetano Veloso, nos capta através do modalismo, da nordestinidade. Ao texto, equivale o contrário: capta-nos pela universalidade. Texto universal, contemporâneo e erudito. Harmonia aberta e ambígua. Acompanhamento instrumental pop vinculado ao texto, atuando como subtexto e contracanto. Esta melodia modal nos remete à música nordestina, genuinamente brasileira, enquanto os outros elementos de arranjo a situam no universo pop, pretensamente universal.

A estruturação rítmica e modal de $O$ Quereres aponta para a relação de uma canção com determinados gêneros musicais, como o repente e a embolada. Nestes gêneros, repentistas improvisam seus versos numa dança de palavras a partir de uma condução rítmica estabelecida, como se esta base musical fixa lhes garantisse a liberdade de associação ideias no fluxo de seu discurso.

Caetano diz que $O$ Quereres foi "tirada de uma estrutura de cordel", e percebemos que seu caráter oral se relaciona à entoação repentista, próxima da embolada que, por sua vez, é parente do coco, também uma dança. Impossível dizer o que vem primeiro: se a dança ou o improviso de embolada. O fato é que percebemos, nestes casos, uma interessante vinculação 
entre música, texto e dança como se fossem galhos provenientes de um mesmo tronco cultural que concilia corpo em movimento, oralidade, voz cantada e palavra escrita. O tratamento original do texto, no entanto, desloca-se da mera reprodução de formas folclóricas, apontando para um tratamento racional do compositor e suas escolhas pelo desenvolvimento da canção através dos substantivos, propondo novas sintaxes.

É bastante comum que o cordelista seja também repentista, ou seja, que possua a habilidade de improvisar versos cantados ao calor da hora. Não deixa de ser uma prova pública de sua capacidade de rimar e dissertar sobre vários temas. O mote para a realização de um repente por vezes é um desafio: disputa entre dois trovadores acompanhados de suas violas. Estes desafios são realizados geralmente a partir de estruturas já existentes como o Galope à Beira Mar, ou o Martelo, por exemplo. A escolha da estrutura equivaleria a uma “escolha de armas" de um duelo. O repente, em outros casos, é uma estória de cordel previamente estabelecida e cantada com acompanhamento instrumental.

Para entendermos este jogo rítmico de pergunta e resposta, basta imaginarmos dois grupos de percussão: substituindo "onde queres revólver" por batidas do primeiro grupo - ou mão esquerda - e "sou coqueiro" por batidas do segundo grupo - ou mão direita - podemos entender a estrutura que define ritmicamente o $T u$ e o $E u$ expressos na canção, também sujeito às rimas internas, como num desafio:

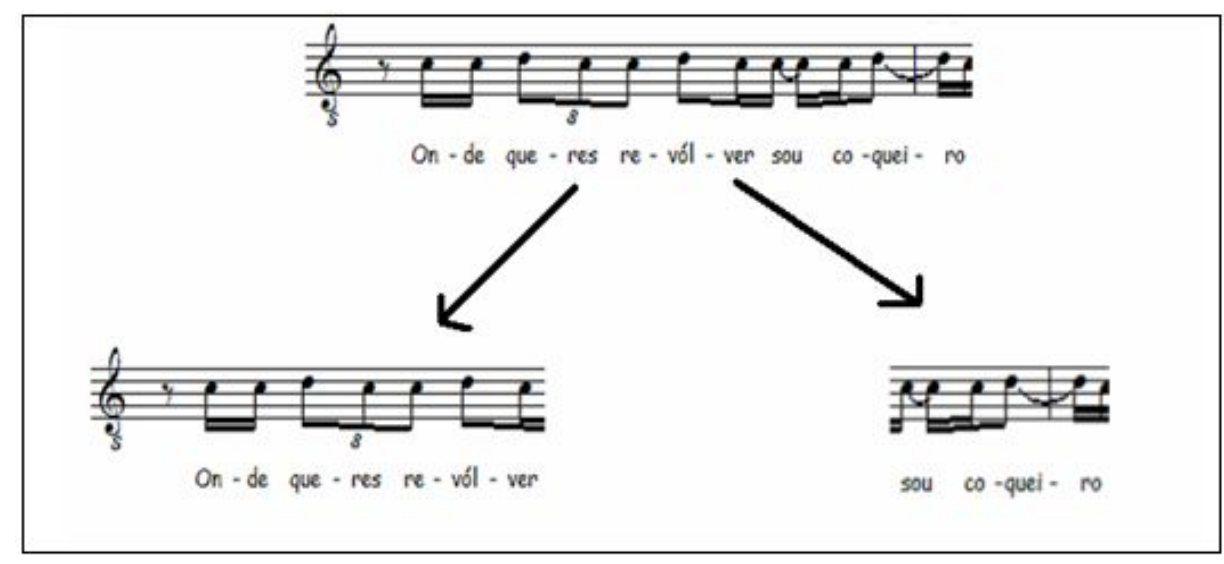




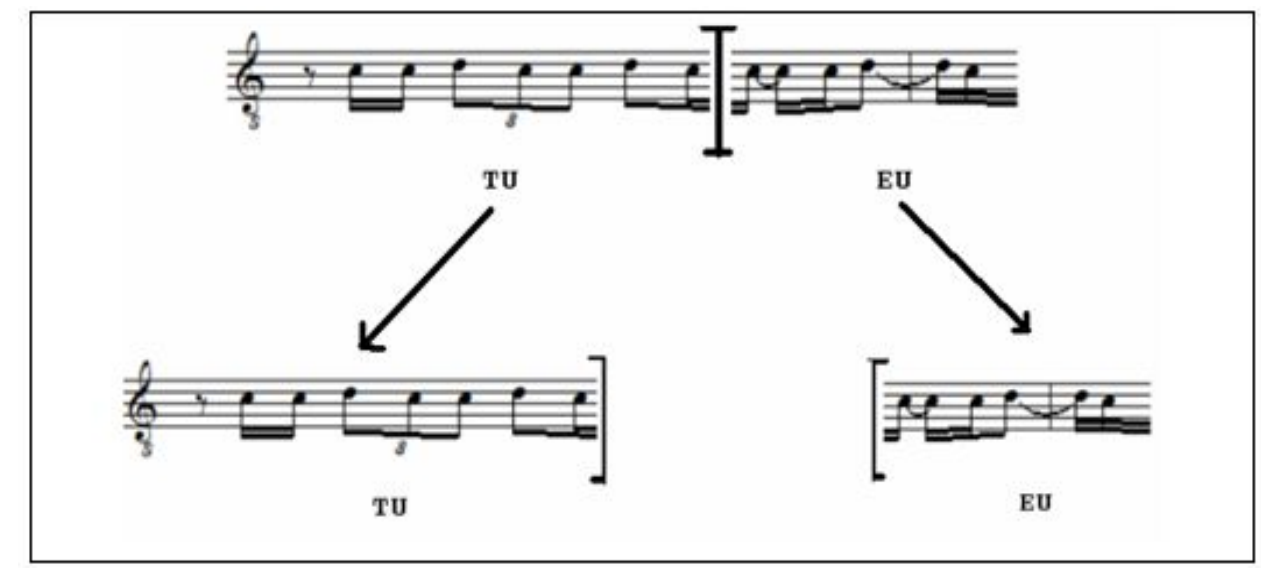

Quando vislumbramos $O$ Quereres a partir de um conceito amplo de dualidade/alteridade, passamos a entender melhor a profunda relação entre o compositor e nossa herança literária. Esta pátria-língua que nos une e nos separa, também faz com que possamos construir nossa identidade em meio às diferenças culturais. A construção da individuação do Brasil se faz através de um processo de assimilação do outro. É o próprio Caetano quem diz que "que o Brasil deve tornar-se o mais diferente de si mesmo que lhe for possível, para encontrar-se" e que "amar a língua portuguesa é amar a sua capacidade como instrumento universal; falar português e livrar-se da prisão do português” (VELOSO, 2005, p. 64).

Encontramos no Soneto 145 de Camões uma estrutura poética semelhante que também reparte o verso em dois, representando a cisão entre amor e pensamento: 


\begin{tabular}{|c|c|}
\hline $\begin{array}{l}\text { Vencido está de Amor } \\
\text { o mais que pode }\end{array}$ & $\begin{array}{l}\text { meu pensamento } \\
\text { vencida a vida, }\end{array}$ \\
\hline $\begin{array}{l}\text { sujeita a vos servir } \\
\text { oferecendo tudo }\end{array}$ & $\begin{array}{l}\text { instituída, } \\
\text { a vosso intento. }\end{array}$ \\
\hline $\begin{array}{l}\text { Contente deste bem, } \\
\text { ou hora em que se viu } \\
\text { mil vezes desejando } \\
\text { outra vez renovar }\end{array}$ & $\begin{array}{l}\text { louva o momento, } \\
\text { tão bem perdida; } \\
\text { a tal ferida, } \\
\text { seu perdimento. }\end{array}$ \\
\hline $\begin{array}{l}\text { Com essa pretensão } \\
\text { a causa que me guia } \\
\text { tão estranha, tão doce, }\end{array}$ & $\begin{array}{l}\text { está segura } \\
\text { nesta empresa, } \\
\text { honrosa e alta. }\end{array}$ \\
\hline $\begin{array}{l}\text { Jurando não seguir } \\
\text { votando só por vós } \\
\text { ou ser no vosso amor }\end{array}$ & $\begin{array}{l}\text { outra ventura, } \\
\text { rara firmeza, } \\
\text { achado em falta. }\end{array}$ \\
\hline
\end{tabular}

A interessante disposição deste poema sobre o papel possibilita diversas leituras. Sabiamente Camões o separa criando mais de uma possibilidade de significação. Roçando a língua de Luís de Camões ${ }^{8}$, O Quereres também apresenta a dualidade associada à antítese. Os paradoxos se revelam necessários para descrever o sentimento indescritível. Vale lembrar o conhecido Soneto 5 que expressa o "não querer mais que bem querer", "contentamento descontente", "tão contrário a si é o mesmo Amor".

“Tão contrário a si” é equivalente a "do querer que há e do que não há em mim". Existem muitas semelhanças entre $O$ Quereres e a poesia de Camões. O poeta luso é mestre na utilização dos substantivos para expressar o amor e o desejo: fogo, ferida, contentamento, dor. Também sente a necessidade da utilização do recurso da substantivação: um não querer, um andar, um nunca contentar-se, um cuidar. Também faz uso de termos "infinitivamente pessoais": querer, servir, ter alguém. Querer sem querer. O desejar com seus conflitos, antíteses, contradições e paradoxos.

Caetano, em Velô, se mostra barroco e tropicalista, baiano e português. Cordelista, rapper e repentista. Cantador, poeta e cantautor, Caetano é camoniano ao explorar o decassílabo que caracteriza Os Lusíadas, fazendo nascer um soneto através do repente como se fosse um improviso de embolada. De fato, em O Quereres a melodia parece mais antiga do

\footnotetext{
${ }^{8}$ Trecho de Língua (Caetano Veloso, Velô, 1984).
} 
que o texto, pois temos uma melodia modal - quase medieval em seus madrigalismos - e um texto "abarrocado", rebuscado, intrincado que obedece a outro sistema de composição. A novidade é a tradição transposta ao palco, ao disco e à canção. Eis que Caetano cita Antonio Candido para se referir ao conceito de barroco:

\begin{abstract}
Antonio Candido define o barroco como a atitude estética em que "a palavra é considerada algo maior que a natureza, capaz de sobrepor-lhe as suas formas próprias"; no romantismo ela "é considerada menor que a natureza, incapaz de exprimi-la, abordando-a por tentativas fragmentárias"; enquanto o classicismo a considera "equivalente à natureza, capaz de criar um mundo de formas ideais que exprimam objetivamente o mundo das formas naturais. (VELOSO, 1997, p. 257).
\end{abstract}

Onde queres o sim e o não: talvez; e onde vês eu não vislumbro razão. Tradicionalmente, sentimento e razão se põem contrários numa luta constante, ao ponto de deixarem de ser o que são. Perdido está de amor meu pensamento. Eunuco e garanhão. Dulcíssima prisão. Eu te quero e não queres como sou, não te quero e não queres como és: A presença do barroco talvez seja uma bela lente para a leitura das manifestações brasileiras até os dias atuais. A "palavra maior que a natureza" talvez seja uma chave muito importante para entendermos $O$ Quereres.

Um contrário com outro por vencer. O quereres e o estares sempre a fim do que em mim é de mim tão desigual. Os cruzamentos são vários, na vida e na obra de Caetano, na busca de um estranhamento que faça refletir a própria obra. Fischer aponta:

Caetano realiza (...) o ideal do artista-crítico, que não apenas produz sua obra, mas também a faz dobrar-se sobre a matéria-prima de que se serve, para analisá-la, para examiná-la, para torná-la objeto de estranhamento e depois objeto de nova familiaridade. (FISCHER, 2001, p. 133).

Camões, enfim, nos explica no Soneto 55 um pouco das contradições em Caetano: 
Sempre a Razão vencida foi de Amor; mas, porque assi o pedia o coração, quis Amor ser vencido da Razão. Ora que caso pode haver maior!

Novo modo de morte, e nova dor! Estranheza de grande admiração, que perde suas forças a afeição, porque não perca a pena o seu rigor.

Pois nunca houve fraqueza no querer, mas antes muito mais se esforça assim um contrário com outro por vencer.

Mas a Razão, que a luta vence, enfim, não creio que é razão; mas há de ser inclinação que eu tenho contra mim.

Estranhamento que cresce até o amor não se reconhecer mais amor e razão não ter mais razão de ser. Affonso Romano de Sant'anna afirma:

\footnotetext{
Engana-se quem pensa que o Barroco é apenas sinônimo de arte nebulosa, hermética, hiperbólica, exageradamente elíptica e derramada. Isto, sem dúvida, existe em Góngora, Bach e Borromini. Mas, atrás dessa vulcânica expressão formal, há uma estrutura rigorosa, matemática e racional. Portanto, reformemos nosso conceito de Barroco: ele é um assombroso encontro entre razão e emoção. (...) Portanto, creiam-me, Barroco é luz e sombra, razão e emoção, matemática e numerologia. Ou melhor, Barroco é matemágica. (SANT’ANNA, s/d).
}

Onde queres mistério eu sou a luz. Interessante a reflexão sobre o barroco enquanto "matemágica", ou a arte de equilibrar emoção e razão, a luz e a sombra, o mistério e a ciência. O arroubo tratado com equilíbrio. O que Affonso Romano de Sant'Anna atribui a João Cabral de Melo Neto poderia nos auxiliar a entender Caetano Veloso - em especial de considerarmos o grande apreço que o cancionista atribui ao autor de Educação pela Pedra: "Meu poeta favorito - e o que eu mais extensamente li - era João Cabral de Melo Neto. E diante dele tudo parecia derramado e desnecessário.” (VELOSO, 2005, p. 55)

Caetano situa seu fazer entre duas personalidades com o nome de João: Cabral, o poeta sem música e Donato, o pianista avesso às palavras. Trilhando um caminho próprio que não é só letra nem só música, o texto não se deixa fixar somente como texto. A música não se 
faz sozinha. Caetano se posiciona por oposição a estas duas figuras. Uma terceira via entre a poesia e a música.

Nesta mesma conferência sobre João Cabral, Sant'Anna comenta a poesia dos autores conceitistas, como Gregório de Matos, que utilizaram magistralmente os jogos de palavras: "o todo e as partes". Assim o autor vislumbra João Cabral - que faz girar "as mesmas vinte palavras ao redor do sol”, um universo constituído de poucas palavras e infinitas ideias. A palavra barroca que é considerada "maior que a natureza", para Candido e Caetano.

Se a parte sem o todo não é parte. $\mathrm{O} E u$ se configura no mundo das coisas. $\mathrm{O} E u$ presente nas coisas, como faz João Cabral em sua poética bipartida das comparações e das transformações. Em essência - que inclui forma - O Quereres é sensivelmente cabralina, conciliando rigor formal, razão e delicadeza. A educação pelas coisas é transposta a uma individuação através do outro, feita por intermédio das coisas do mundo.

O Quereres pode ser entendida como uma canção em que o compositor pensa o desejo e encontra o eu, utilizando-se do recurso narrativo em segunda pessoa. É interessante pensarmos $O$ Quereres a partir das coisas. O próprio querer é coisificado pelo recurso da substantivação - enquanto remete objetos que se alternam infinitamente no decorrer da canção, só permanecendo o desejo que os liga. O discurso de imagens que associam coisas, pessoas e fatos, nos mergulha num sonho onde as coisas e os bichos falam como se fossem gente, onde o eu se transforma constantemente e onde tudo se desloca num passe de mágica. Objetos e sentimentos se deslocam no espaço: de Leblon a Pernambuco, de um canto ao mundo inteiro; no tempo: de quaresma a fevereiro; e se metamorfoseiam num "deslizamento permanente do ser" (WISNIK in CHEDIAK, 1988, p. 16).

Tudo isto nos remete à dimensão do sonho, tão importante para a psicanálise. Temos Eu e Outro ligados pelo desejo desencontrado de ambos, numa comunicação por meio de imagens oníricas que se codificam numa linguagem do inconsciente. No verbete desejo, do Dicionário de Psicanálise, “a consciência só pode dizer "eu” em relação a um outro que lhe serve de apoio: eu me reconheço no outro na medida em que o nego como outro. (ROUDINESCO e PLOT, 1998, p. 146).

A negação como outro ocupa o centro de O Quereres. Temos, nesta canção, o constante contraste entre duas pessoas que são afetivamente envolvidas. Percebemos claramente a constituição do eu a partir do outro através do processo de negação e identidade. A afirmação do eu é identificada na interpretação de Caetano quando utiliza o vibrato, 
conforme vimos nas Considerações Temáticas. O Quereres poderia conduzir-nos a diversas reflexões que remontam à trajetória do conceito de desejo na Filosofia e na Psicanálise. Cabe-nos, para compreender a dimensão da citação anterior, abordar o conceito de eu e outro:

Para Lacan, o eu se distingue, como núcleo da instância imaginária, na fase chamada de estádio do espelho. A criança se reconhece em sua própria imagem, causionada nesse movimento pela presença e pelo olhar do outro (a mãe ou um substituto) que a identifica, que a reconhece simultaneamente nessa imagem. (ROUDINESCO e PLOT, 1998, p. 212).

$\mathrm{Na}$ fase do espelho, compreendida até os dezoitos meses de vida segundo a teoria lacaniana, ocorre o processo de individuação do ser humano. Jacques Lacan concilia um estudo da gênese do eu a partir da filosofia hegeliana e da teoria de Freud. A expressão estádio do espelho designa "um momento psíquico e ontológico da evolução humana (...), durante a qual a criança antecipa o domínio sobre sua unidade corporal através de uma identificação com a imagem do semelhante e da percepção de sua própria imagem num espelho" (ROUDINESCO e PLOT, 1998, p. 194). Poderíamos vislumbrar, em O Quereres, uma espécie de espelho amoroso como fase da vida das pessoas adultas. O relacionamento como resultado da identificação com a pessoa amada - este olhar do outro no qual se reflete e corporifica nosso próprio interior.

A relação do compositor com a psicanálise não é de todo absurda. Segundo Caetano Veloso, a canção Araçá Azul - homônima do disco de caráter marcadamente experimental foi composta a partir de um sonho contado ao colega Rogério, que dividia moradia no Solar da Fossa, no Rio de Janeiro. Mesmo não sendo psicanalista, Rogério realizou "uma interpretação amadora bastante consistente" (VELOSO, 2002, p. 23). Chama-nos atenção o fato de existir numa letra tão curta a existência do sonho e da morte, tão importantes para a psicanálise. A canção Araçá Azul é, segundo o próprio compositor, muito importante para a sua própria afirmação pessoal. ${ }^{9}$ Neste sentido, esta canção nos chama atenção para a dimensão do sonho na obra de Caetano, e podemos perceber isso em O Quereres, onde a linguagem utilizada marca as imagens em mutação que dialogam entre si, embora a última seja um despertar que rompe o amor narcísico da projeção no outro para a construção da individuação e do relacionamento maduro.

\footnotetext{
${ }^{9}$ Cabe conferirmos sobre esta obra de Caetano a bela dissertação de Peter Dietrich intitulada: Araçá Azul, uma análise semiótica. São Paulo, 2003.
} 
O Narcisismo como evento psíquico é pesquisado há muito tempo por estudiosos de diversas áreas. Sua classificação abrange desde a perversão até uma abordagem mais recente que também o considera essencial na teoria do desenvolvimento sexual humano:

Para Jacques Lacan, o narcisismo originário constitui-se no momento em que a criança capta sua imagem no espelho, imagem esta que, por sua vez, é baseada na do outro, mais particularmente da mãe, constitutiva do eu. O período do autoerotismo, portanto, corresponde à fase da primeira infância, período das pulsões parciais e do "corpo despedaçado", marcado por aquele "desamparo originário" do bebê humano cujo retorno sempre possível constitui uma ameaça, a qual se encontra na base da agressividade (ROUDINESCO e PLOT, 1998, p. $532)$.

Podemos observar que este "narcisismo originário" faz parte do desenvolvimento deste "eu" que se baseia necessariamente na relação com o outro. $\mathrm{O}$ desejo se dá a partir do momento em que se supera o narcisismo originário, ou seja, quando o "eu” já está plenamente constituído e a pessoa consegue distinguir-se do outro. E, querendo-te, aprender o total do querer que há e do que não há em mim. A individuação através da relação com o outro.

O desejo em toda a sua complexidade. O desejo em si e por si só. Desejo que habita o inconsciente e faz do sonho e das imagens a sua própria linguagem. Infinitivamente Pessoal porque desejar não tem fim, porque o desejo é essencialmente humano, porque não se submete às regras. $\mathrm{O}$ desejo tem uma sintaxe própria, não respeita a gramática. Talvez por todos esses motivos, existam tantas antíteses ao ponto de fazer confrontarem-se até mesmo as coisas inanimadas, como se fossem pessoas de desejo.

Plenamente consciente da ambiguidade da língua inglesa do ser/estar, Caetano parece responder a Bob Dylan - eu não sou quem você quer, meu bem, eu não sou quem você precisa - transformando o pronome "quem" em "que" e deslocando o pronome "que" para o advérbio de lugar "onde”. Caetano, assim, localiza o desejo na dimensão espacial, na concretude das coisas.

O Quereres, como podemos perceber, é um pensar que necessita atingir os limites da sua própria linguagem, para se realizar plenamente, em transcendência. Através da canção, Caetano parece fundir o querer ao ser, o desejo que é inerente à condição humana: O quereres (seres) e o estares sempre a fim do que em mim é de mim tão desigual.

Para Caetano Veloso, a forma que melhor conjuga pensamento e linguagem em português é, portanto, a canção. Talvez o discurso apresentado em O Quereres somente seja possível através deste gênero. Liberdade, síntese, profundidade, polissemia e forma em três 
minutos. Interessante esta abordagem do desejo numa canção, ainda mais se considerarmos que na língua da filosofia por excelência, três palavras abarcam em alemão a noção de desejo, para a qual a língua francesa e a língua espanhola dispõem apenas de um único termo (désir, deseo): Begierde, Lust e Wunsch. (ROUDINESCO E PLOT, 1998, p. 146).

Transcender a linguagem, na canção brasileira equivale a filosofar em alemão, para Caetano. Em O Quereres não temos apenas três palavras para designar o desejo, mas a série talvez infinita - de substantivos e substantivações da língua portuguesa. Este filosofar através da linguagem das coisas se potencializa na música, ou melhor: é através da música que surgem as palavras, assim como é a estrutura musical que embasa o improviso dos cantadores repentistas e a articulação de seu fluxo de pensamento. Verificamos a íntima relação entre letra e música durante todo este trabalho, quando vimos os mínimos detalhes da construção dos temas e motivos musicais: a dualidade entre as notas dó e ré, como se a primeira representasse o $E u$ presente em todos os acordes da canção. Fragmentado e uno ao mesmo tempo, complexo. Algo que permanece em essência mesmo disfarçado e re-contextualizado em diferentes situações. 


\section{BIBLIOGRAFIA}

CAMÕES, Luís Vaz de. Sonetos. Disponível em: <http://www.bibvirt.futuro.usp.br>, Acessado em 20 fev. 2007.

CHAVES, Celso Loureiro; NUNES, Leonardo Assis. Armando Albuquerque e os poetas. Per Musi: Revista de Performance Musical, vol 8 p. 66-73. Belo Horizonte, 2003.

CHAVES, Celso Loureiro. Memórias do pierrô lunar e outras histórias musicais. Porto Alegre: L\&PM, 2006.

CHEDIAK, Almir. Songbook Caetano Veloso, vol 2. Rio de Janeiro: Lumiar Editora, 1988.

DAll'AlBA, Eduardo. Noite e Música na Poesia de Carlos Drummond de Andrade. Tese de Doutorado. Porto Alegre: AGE, 2003.

DIETRICH, Peter. Araçá Azul: uma análise semiótica. 2003. 197 p. Dissertação (Mestrado em Semiótica e Lingüística Geral). Departamento de Lingüística da Faculdade de Filosofia, Letras e Ciências Humanas. Universidade de São Paulo, São Paulo, 2003.

DOURADO, Henrique Autran. Dicionário de termos e expressões da música. São Paulo: Editora 34, 2004.

FISCHER, Luís Augusto. Contra o Esquecimento: crônicas de ideias. Porto Alegre: Artes e Ofícios, 2001.

MATTOS, Fernando Lewis de. A salamanca do jarau de Luís Cosme: análise musical e história da recepção crítica. 1997. 268 p. Dissertação (Mestrado em Música). Curso de Pós-Graduação em Música. Universidade Federal do Rio Grande do Sul, Porto Alegre, 1997.

MELO NETO, João Cabral de. Poesias Completas (1940 - 1965). Rio de Janeiro: José Olympio, 1979, $3^{\text {a }}$ ed.

MEYER, Leonard B. Explaining Music: Essays and Explorations. Chicago: Phoenix Edition, 1978.

OLIVEIRA, Solange Ribeiro de. Literatura e Música. São Paulo: Perspectiva, 2002.

ROUDINESCO, Elisabeth; PLOT, Michel. Dicionário de Psicanálise. Rio de Janeiro: J. Zahar, 1998. 
SANT'ANNA, Affonso Romano de. Música Popular e Moderna Poesia Brasileira. São Paulo: Landmark, 2004, $4^{\mathrm{a}}$ ed.

. Outro Cabral, barroco. Artigo eletrônico. Disponível em: $<$ http://www.palavrarte.com/Artigos_Resenhas/artigos_aromano.htm $>$ Acessado em 28 fev. 2007.

SHOENBERG, Arnold. Fundamentos da Composição Musical. São Paulo: Editora da Universidade de São Paulo, 1996, $3^{\text {a }}$ ed.

TATIT, Luiz. O Cancionista: composição de canções no Brasil. São Paulo: EDUSP, 2002, $2^{\mathrm{a}} \mathrm{ED}$.

O Século da Canção. São Paulo: Ateliê Editorial, 2004.

. Canção - eficácia e encanto. São Paulo: Atual, 1986.

VELOSO, Caetano. Velô. Polygram, 1984.

O Mundo não é chato. Apresentação e Organização Eucanaã Ferraz. São Paulo: Companhia das Letras, 2005.

Verdade Tropical. São Paulo: Companhia das Letras, 1997.

Letra Só; Sobre as Letras. Seleção e organização de Eucanaã Ferraz.

São Paulo: Companhia das Letras, 2003.

Recebido em 23/09/2019. Aceito em 09/12/19. 